\title{
Effects of Nano-sized Bee Pollen as a New Cosmetic Ingredient
}

\author{
Hae-In Pyeon ${ }^{1}$, Jia Bak ${ }^{1}$, Jin-I Seok ${ }^{1}$, Soojeong So ${ }^{2}$, Hwa-Jin Suh ${ }^{3}$, Mikyung $\mathrm{Oh}^{2}$, Segi Kim ${ }^{1}$, Chung-Eun Yang ${ }^{4}$, II Kyung Chung ${ }^{5 *}$, Yun-Sik Choi ${ }^{1 *}$ \\ ${ }^{1}$ Department of Pharmaceutical Science and Technology, Catholic University of Daegu, Gyeongsan-si, Gyeongsangbuk-do, Korea \\ ${ }^{2}$ Institute in Natural Science Technology, Gyeongsan-si, Gyeongsangbuk-do, Korea \\ ${ }^{3}$ GBTP-GNC, Yeongcheon-si, Gyeongsangbuk-do, Korea \\ ${ }^{4}$ Department of Fashion Design, Catholic University of Daegu, Gyeongsan-si, Gyeongsangbuk-do, Korea \\ ${ }^{5}$ Department of Biotechnology, Catholic University of Daegu, Gyeongsan-si, Gyeongsangbuk-do, Korea
}

\begin{abstract}
"Corresponding authors: Yun-Sik Choi, Department of Pharmaceutical Science and Technology, Catholic University of Daegu, 13-13 Hayang-ro, Hayang-eup, Gyeongsan-si, Gyeongsangbuk-do 38430, Korea

Tel.: +8253850 2561

Fax: +8253 3596821

Email: tiana@cu.ac.kr

II Kyung Chung, Department of Biotechnology, Catholic University of Daegu, 13-13 Hayang-ro, Hayang-eup, Gyeongsan-si, Gyeongsangbukdo 38430 , Korea

Tel.: +8253 8503178

Fax: +82533596821

Email: chungik@cu.ac.kr

Yun-Sik Choi and II Kyung Chung contributed equally to this work.
\end{abstract}

Received September 11, 2016

Revised January 30, 2017

Accepted February 8, 2017

Published March 30, 2017

\begin{abstract}
Purpose: Bee pollen is largely composed of pollen gathered by worker bees and is well known as a complete nutritional food. Bee pollens are rich in protein (approximately 40\%), free amino acids, and flavonoids. However, bee pollen is covered by an outer wall called exine, which is resistant to digestive enzymes, acids, and bases. Therefore, utilizing bee pollen for nutritional and medical purposes has been limited. In this study, we removed the exine layer with wet-grinding technology and evaluated its anti-oxidant activity, protective effects on skin fibroblasts, and potential clinical application as a cosmetic. Methods: We prepared nano-sized bee pollen with wet-grinding technology and examined its radical scavenging activity and cell protective effects. We performed a clinical study after preparing the nanosized bee pollen. Results: Bee pollen showed good anti-oxidant activity, and $1 \%$ bee pollen reduced lactate dehydrogenase (LDH) release $18.73 \%$ by skin fibroblasts. In addition, the clinical study showed that bee pollen had beneficial effects on skin roughness, hydration, transparency, wrinkles around the eyes, and the melanin index. Furthermore, bee pollen did not induce any adverse effects on the skin. Conclusion: These data indicate that bee pollen is a good cosmetic resource that provides diverse beneficial effects to the skin.
\end{abstract}

Keywords: Bee pollen, Anti-oxidant, Cosmetics, Protection, Wet-grinding technology

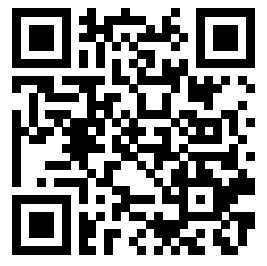

\section{Introduction}

벌 화분은 꽃가루가 꿀 및 벌의 침과 함께 응집된 물질로 예로 부터 영양분 섭취뿐만 아니라 의학적 용도로 사용되어 온 천연 물 질이다(Nogueira et al., 2012). 벌 화분은 탄수화물, 단백질, 아 미노산, 지질, 비타민, 미네랄 등이 풍부할 뿐만 아니라 flavonoid
를 비롯한 많은 양의 polyphenol 성분을 함유하고 있다(Orzáez Villanueva et al., 2002). 벌 화분의 효능으로는 세포 증식과 피부 재생을 촉진하고, 혈중 콜레스테롤 저하, 체내 해독작용, 항산화 효 과, 양성 전립선 비대증의 완화 등이 잘 알려져 있다(Baltrušaityte et al., 2007; Morais et al., 2011).

최근의 연구에 의하면 벌 화분에는 flavonoid가 약 $1.4 \%$ 를 차지 
하며 주로 kaempferol, quercetin, isorhamnetin 등으로 구성되어 있는 것으로 알려져 있다(Komosinska-Vassev et al., 2015; Lee et al., 2016). 이들 flavonoid류는 다양한 약리학적 효능을 갖고 있 는데, 예를 들어 quercetin은 자외선 조사에 따른 cyclooxygenase 2 와 nuclear factor kappa $\mathrm{B}$ 의 활성을 억제하여 피부세포의 염증 을 억제하고, 항산화 작용이 강하여 신경세포를 비롯한 다양한 세 포에서 보호작용이 있는 것으로 알려져 있다(Sharma et al., 2016; Zhu et al., 2016). 마찬가지로 isorhamnetin은 항산화 기능을 담당 하는 nuclear factor-erythroid 2-related factor 2 단백질을 활 성화하여 세포보호작용을 나타내고, mitogen-activated protein kinase kinase 1 과 phosphatidylinositide 3-kinase의 신호전달을 억제하여 피부암을 억제한다(Kim et al., 2011; Yang et al., 2014). 이러한 일련의 결과들은 벌 화분이 항산화 작용 및 자외선으로부 터의 피부 보호와 염증을 억제하므로 화장품 원료로의 개발 가능 성을 제시한다.

벌 화분이 다양한 효능을 갖고 있음에도 불구하고 화장품이나 연고 등 외용으로의 이용에는 어려움이 있었다. 그 이유로 벌 화분 은 외피(exine)라고 하는 두터운 외막으로 둘러싸여 있고 외피는 생물의 소화효소는 물론이고 산이나 알칼리에 잘 분해되지 않는다. 이에 따라 경구로 섭취할 때 생체이용률은 10-15\%에 불과한 것으 로 알려져 있다(Komosinska-Vassev et al., 2015). 이를 극복하기 위하여 최근에 본 연구진은 습식 나노 분쇄 기술을 활용하여 벌 화 분의 생리활성물질의 추출을 획기적으로 증가시킬 수 있음을 보고 하였다(Choi et al., 2016). 즉 $3 \mathrm{~h}$ 동안의 습식 나노 공정을 통하여 phenol 화합물의 유출이 10배 이상 증가하고, 2,2-azino-bis(3ethylbenzothiazoline-6-sulphonic acid) (ABTS) 방법으로 측정할 때 항산화 활성이 5.78 배 향상되는 것을 관찰하였다. 이러한 결과 는 벌 화분도 습식 나노 공정을 통하여 생리활성물질의 유출이 획 기적으로 증가하므로 화장품을 비롯한 외용 제제로서 충분히 개발 가능함을 의미한다.

이에 착안하여 본 연구에서는 습식 나노 공정을 거친 나노화 벌 화분 을주성분으로 하는 화장품을 제조하여 효능과 독성에 대해 연구하였다.

\section{Methods}

\section{1. 벌 화분의 습식 나노 분쇄}

벌 화분은 전라북도 남원과 경상남도 산청의 벌 화분 농가를 통해 구입하였다. 벌 화분의 습식 나노 분쇄 공정은 이미 보고된 논문에 소개되어 있다(Choi et al., 2016). 이를 간단히 소개하면 습식 분쇄기 (Rotate Mill; Ilsin Nanotechnology, Japan)를 이용하여 벌 화 분을 $3 \mathrm{~h}$ 동안 분쇄한 것으로, 분쇄된 입자 크기의 분포도는 입도분 석기(Mastersizer 2000; Malvern Instruments, UK)를 이용하여 확인하였다.

\section{2. 나노화 벌 화분의 항산화 효능}

나노화 공정을 거친 벌 화분의 항산화 효능을 측정하기 위해 1,1-diphenyl-2-picrylhydrazyl radical (DPPH; Sigma-Aldrich, USA)을 메탄올에 $0.1 \mathrm{mM}$ 농도로 녹인 후 $1 \mathrm{~mL}$ 를 $100 \mathrm{mM}$ Tris buffer $450 \mu \mathrm{L}$, 나노화 벌 화분의 반응액(0.5\% 또는 $1 \%) 50 \mu \mathrm{L}$ 와 혼합 한 후 차광하여 실온에서 $30 \mathrm{~min}$ 동안 반응시켰다. $\mathrm{DPPH}$ 라디칼 제 거 활성은 흡광분석기(AMR-100; Hangzhou Allsheng Instruments, China)를 이용하여 $517 \mathrm{~nm}$ 의 파장에서 측정하였다(Choi et al., 2016). 양성 대조군으로는 vitamin C (Sigma-Aldrich) $0.1 \%$ 를 이용하였고 vitamin C에 대한 상대적 효능을 비교 평가하였다.

상대적 효능 $(\%)=\frac{\text { 음성 대조군의 흡광도-나노화 벌 화분 반응액의 흡광도 }}{\text { 음성 대조군의 흡광도-vitamin C의 흡광도 }} \times 100$

\section{3. 나노화 벌 화분의 세포보호효과}

나노화 벌 화분의 세포보호효과는 CCD-986sk (KCLB No. 21947; Korean Cell Line Bank, Korea) 세포주를 이용하여 평가 하였다. 이를 위해 $10 \%$ fetal bovine serum (GenDEPOT, USA)과 $1 \%$ penicillin/streptomycin (Gibco ${ }^{\mathrm{TM}}$, Thermo Fisher Scientific, USA)을 함유하는 Dulbecco's Modified Eagle's Medium (DMEM) with high glucose with L-glutamine and sodium pyruvate (GenDEPOT)을 이용하여 24 well plate에서 $1 \times 10^{5}$ cells/well의 밀 도로 세포를 배양하였다. 세포 독성은 나노화 벌 화분이 $0.1 \%$ 또 는 $1 \%$ 의 농도가 되도록 배양액을 만든 후 $6 \mathrm{~h}$ 동안 배양하고 배양 액에 분비된 $\mathrm{LDH}$ 활성을 측정하여 확인하였다. $\mathrm{LDH}$ 활성은 $\mathrm{LDH}$ cytotoxicity assay kit (Cayman Chemical, USA)의 사용방법에 따라 배지 상층액과 반응액(lactic acid, nicotinamide adenine dinucleotide, tetrazolium salt, diaphorase를 assay buffer 이용 하여 각각 $1: 100$ 으로 희석)을 $1: 1$ 로 혼합하고 차광한 상태로 실온에서 $30 \mathrm{~min}$ 동안 반응 후 흡광분석기의 $490 \mathrm{~nm}$ 파장에서 측정하였다.

\section{4. 나노화 벌 화분을 포함하는 앰플의 임상효능시험}

\section{1) 시험 방법}

나노화 벌 화분을 포함하는 앰플의 피부 결, 피부 수분, 눈가 주 름, 피부 투명도, 멜라닌 개선 효과를 측정하기 위하여 30-65세의

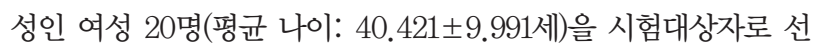
정하여 임상시험을 진행하였다. 임상시험은 임상시험 전문 기관인 $\mathrm{KC}$ 피부임상연구센터에 의뢰하였고 $\mathrm{KC}$ 피부임상연구센터는 가톨 릭관동대학교 국제성모병원 피부과의 책임하에 임상시험을 진행 하였다. 시험대상자들은 나노화 벌 화분을 포함하는 앰플을 정해진 시험부위에 4 주간 사용하였고 사용 전, 사용 2 주 후, 사용 4 주 후에 피부 측정을 각각 진행하였다. 
A

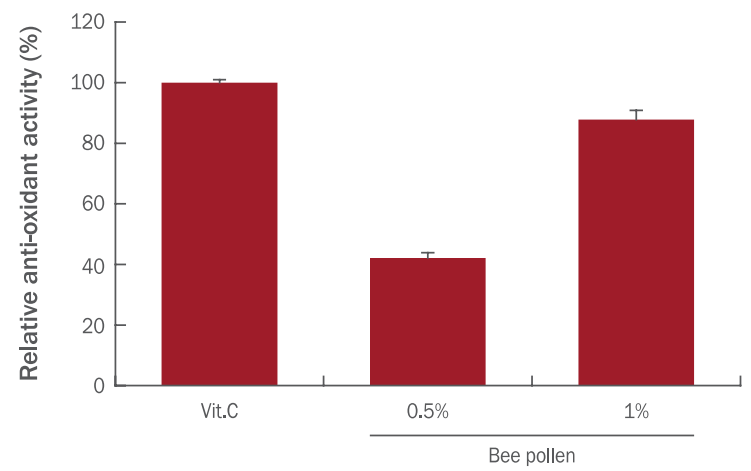

B

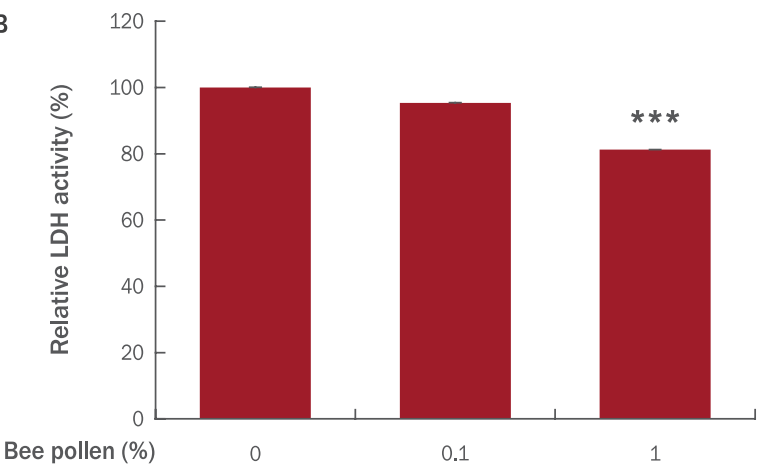

Figure 1. Anti-oxidant effects of bee pollen.

(A) Anti-oxidant effects of bee pollen were examined by the 1,1-diphenyl-2-picrylhydrazyl radical (DPPH) scavenging assay. The bee pollen concentration was $0.5 \%$ or $1 \%$ and $0.1 \%$ vitamin C (Vit. C) was used as a control. The anti-oxidant activities of $0.5 \%$ and $1 \%$ bee pollen were $42 \%$ and $88 \%$ compared to $0.1 \%$ Vit. C, respectively. (B) Cell protective effects of bee pollen were examined by the lactate dehydrogenase (LDH) release assay. CCD-986sk cells were cultured in medium containing $0.1 \%$ or $1 \%$ bee pollen for $6 \mathrm{~h}$, and $\mathrm{LDH}$ activity was measured with a spectrophotometer. LDH activity decreased significantly in the $1 \%$ bee pollen-treated group compared to that in the control. Data are mean \pm standard error $\left(\mathrm{M} \pm \mathrm{S}\right.$.E.). ${ }^{* * *} p<0.001$ compared to control.

\section{2) 평가 방법}

시험대상자들의 피부 결, 피부 수분, 눈가 주름, 피부 투명도 및 멜라닌 개선 효과는 각각 Antera 3D (Miravex, Ireland), Corneometer $^{\circledR}$ CM 825 (Courage+Khazaka Electronic, Germany), Antera 3D (Miravex), Translucency meter TLS850 (Dia-Stron, UK), Mexameter ${ }^{\circledR}$ MX 18 (Courage+Khazaka Electronic)를 이용하여 측정하였다.

\section{5. 나노화 벌 화분을 포함하는 앰플, 세럼, 크림의 피부자극시험}

나노화 벌 화분을 포함하는 앰플, 세럼, 크림의 피부자극을 측

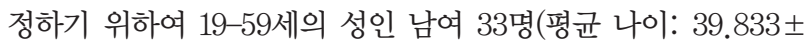
10.100 세)을 시험대상자로 선정하였다. 이를 위하여 시험대상자 의 등 부위를 $70 \%$ 에탄올로 닦아낸 뒤 건조시키고, IQ Chamber (Chemotechnique $\mathrm{MB}$ Diagnostics $\mathrm{AB}$, Sweden)에 시험물질을 각 $20 \mu \mathrm{L}$ 씩 적하한 후 $24 \mathrm{~h}$ 동안 부착하였다. 패치 제거 $1 \mathrm{~h}$, 패 치 제거 $24 \mathrm{~h}$ 후 2 명의 전문가에 의하여 국제접촉피부염연구회 (International Contact Dermatitis Research Group)의 판정기준에 따라 자극정도를 관찰하였다. 피부 반응도와 자극지수는 아래의 식 을 통해 산출하였다.

피부 반응도 $=\left(\frac{\sum_{\mathrm{i}=1}^{\mathrm{n}} \text { 평가값 }}{\mathrm{n} \text { (시험대상자수 })}\right)+\left(\frac{\sum_{\mathrm{i}=1}^{\mathrm{n}} \text { 평가값 }}{\mathrm{n} \text { (시험대상자수 })}\right) 24 \mathrm{~h}$

피부자극지수 $=\frac{\text { 피부 반응도 }}{\mathrm{n} \text { (평가횟수) }}$

\section{6. 통계분석}

통계처리는 paired $t$-test 또는 analysis of variance (ANOVA) 를 이용하여 유의수준을 0.05 ( $p<0.05)$ 로 하여 검정하였다.

\section{Results and Discussion}

\section{1. 나노화 벌 화분의 활성}

먼저 나노화 벌 화분의 항산화 효과를 $0.1 \%$ vitamin $\mathrm{C}$ 를 대조 군으로 하여 $\mathrm{DPPH}$ 측정법으로 평가한 결과, $0.5 \%$ 나노화 벌 화분 은 대조군 대비 $42 \%$ 의 활성을 나타내었다. 반면에 $1 \%$ 나노화 벌 화분은 $0.1 \%$ vitamin $\mathrm{C}$ 대비 $88 \%$ 에 해당하는 높은 활성을 보였다 (Figure 1A). 벌 화분은 kaempferol, naringenin, quercetin 그리고 hesperetin 등 폴리페놀 성분의 함량이 약 1.4-1.6\%를 차지하는 것 으로 알려져 있는데(Fanali et al., 2013; Komosinska-Vassev et al., 2015), 벌 화분은 물리적, 화학적으로 안정한 외피로 둘러싸여 있어 유효성분의 유출이 쉽지 않았다. 그러나 이전의 논문에서 보 고한 바와 같이 나노화 공정을 통해 벌 화분의 폴리페놀 성분 유출 이 11배나 증가할 수 있음을 밝혔다(Choi et al., 2016). 이러한 결과 들은 기존의 방법으로는 피부에 적용하기 어려웠던 벌 화분이 나노 화 공정을 통해 높은 활성을 가질 수 있음을 의미한다.

나노화 벌 화분의 세포보호효과는 CCD-986sk 세포주를 이용하 여 평가하였다. 이를 위해 CCD-986sk세포에 $0.1 \%$ 또는 $1 \%$ 나노 화 벌 화분을 $6 \mathrm{~h}$ 동안 처치한 후 $\mathrm{LDH}$ release assay를 실시하였다. 그 결과, $\mathrm{LDH}$ 의 활성이 대조군에 비해 $0.1 \%$ 와 $1 \%$ 나노화 벌 화분 을 처치한 군에서 각각 $4.64 \%$ 와 $18.73 \%$ 감소하였다(Figure $1 \mathrm{~B}$ ). 본 실험은 독성 물질이나 자외선 조사와 같이 특정 자극을 가한 것 


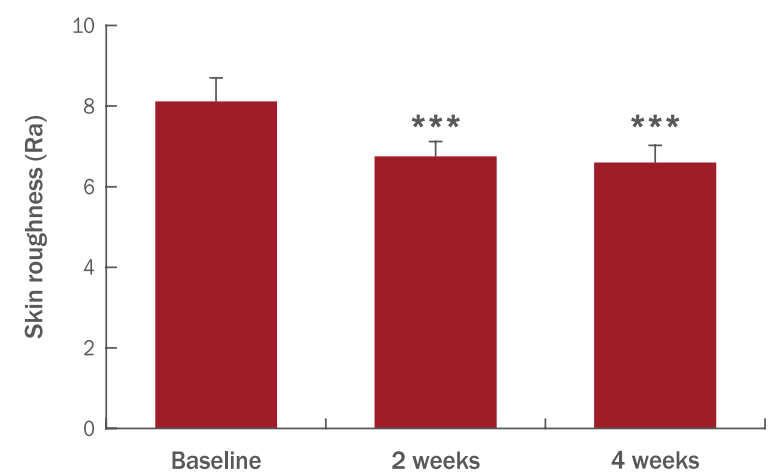

Figure 2. Effects of bee pollen on facial skin roughness.

Twenty volunteers participated in a clinical study, and skin roughness was tested with Antera 3D after applying bee pollen 2 and 4 weeks. Skin roughness was improved at both 2 and 4 weeks after applying bee pollen. Data are $\mathrm{M} \pm$ S.E. ${ }^{* * *} p<0.001$ compared to before bee pollen application.

이 아닌 정상상태에서의 세포보호효과를 알아보기 위한 것이다. 정 상배지에서 자연적으로 발생하는 세포의 손상은 노화 과정에서 나 타나는 자연스러운 세포의 손상과 견주어 생각할 수 있다. 따라서 본 실험 결과는 피부의 노화와 같은 정상적인 세포 손상에 대해 벌 화분의 보호 효과를 나타낼 가능성을 제시하기 위한 것이다.

\section{2. 나노화 벌 화분의 임상효능 평가결과}

나노화 벌 화분의 피부미용 효과를 알아보기 위하여 앰플을 제 조하였다(Table 1). 앰플의 주요 성분은 나노화 벌 화분 $1.50 \%$, 디 프로필렌글라이콜 $5.00 \%$, 부틸렌글라이콜 $3.00 \%$, 나이아신아마 이드 $2.00 \%, 1,2$-헥산디올 $1.90 \%$, 아데노신 $0.04 \%$ 등이다.

\section{1) 피부 결 측정 결과}

나노화 벌 화분을 주성분으로 하는 앰플을 사용한 후 얼굴 볼 부위

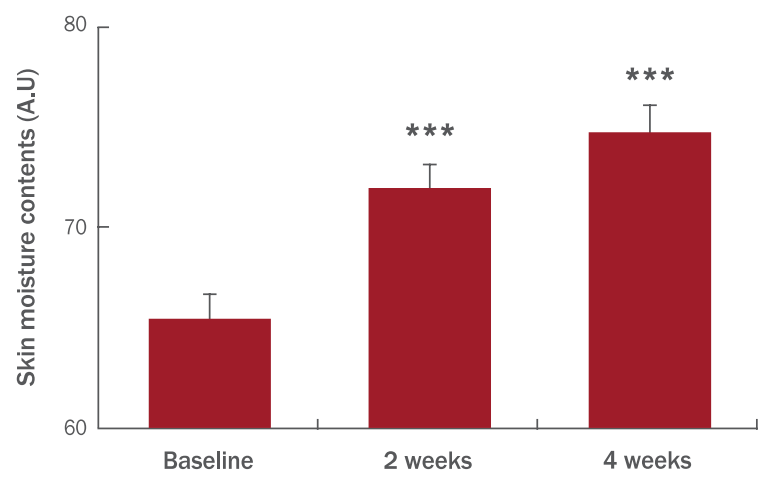

Figure 3. Effects of bee pollen on facial skin moisture contents. Twenty volunteers participated in a clinical study, and skin moisture contents was tested with Corneometer ${ }^{\circledR}$ CM 825 after applying bee pollen 2 and 4 weeks. Skin moisture contents was improved at both 2 and 4 weeks after applying bee pollen. Data are $\mathrm{M} \pm$ S.E. ${ }^{* * *} p<0.001$ compared to before bee pollen application.

에서 피부 결을 측정한 결과, 사용 2 주만에 $14.2 \%$ 의 개선율을 보였다. 사용 4 주 후에 측정한 결과에서는 $16.8 \%$ 의 개선율을 보였다(Figure 2).

2) 피부 수분 측정 결과

나노화 벌 화분을 주성분으로 하는 앰플을 사용한 후 얼굴 볼 부위 에서 피부 수분을 측정한 결과, 사용 2 주만에 $10.0 \%$ 의 개선율을 보였 다. 사용 4 주 후에 측정한 결과에서는 $14.2 \%$ 로 보다 증가된 개선율을 보 였으나, 2 주 후의 결과와 비교할 때에는 유의한 차이를 보이지 않았다 (Figure 3).

3) 눈가 주름 측정 결과

나노화 벌 화분을 주성분으로 하는 앰플을 사용한 후 눈가의 주 름을 측정한 결과, 사용 2 주만에 $18.0 \%$ 의 개선율을 보였다. 사용

Table 1. Major components of ampoule, serum, and cream

\begin{tabular}{lccc}
\hline Components & Ampoule (\%) & Serum (\%) & Cream (\%) \\
Bee pollen & 1.50 & 0.75 & 0.75 \\
Dipropylene glycol & 5.00 & - & - \\
Butylene glycol & 3.00 & - & 3.00 \\
Niacinamide & 2.00 & 2.00 & 2.00 \\
1,2-Hexanediol & 1.90 & Q.S. & 1.70 \\
Adenosine & 0.04 & 0.04 & 0.04 \\
Arginine & 0.16 & - & 0.16 \\
Propolis extracts & 0.30 & 0.20 & - \\
Glycerine & Q.S. & 7.00 & - \\
Distilled water & 70.67 & 72.03 & 63.73 \\
\hline
\end{tabular}

Q.S., quantum satis (the amount which is enough). 


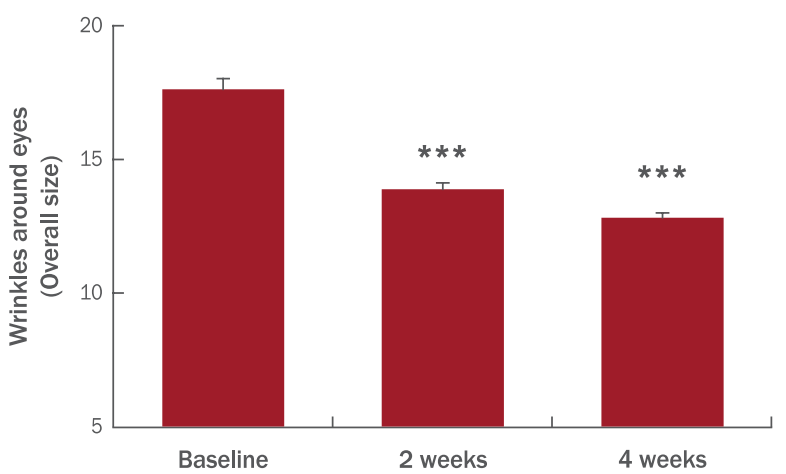

Figure 4. Effects of bee pollen on wrinkles around the eyes. Twenty volunteers participated in a clinical study, and wrinkles around the eyes were tested with Antera 3D after applying bee pollen 2 and 4 weeks. Wrinkles around the eyes were decreased at both 2 and 4 weeks after applying bee pollen. Data are $\mathrm{M} \pm$ S.E. ${ }^{* * *} p<0.001$ compared to before bee pollen application.

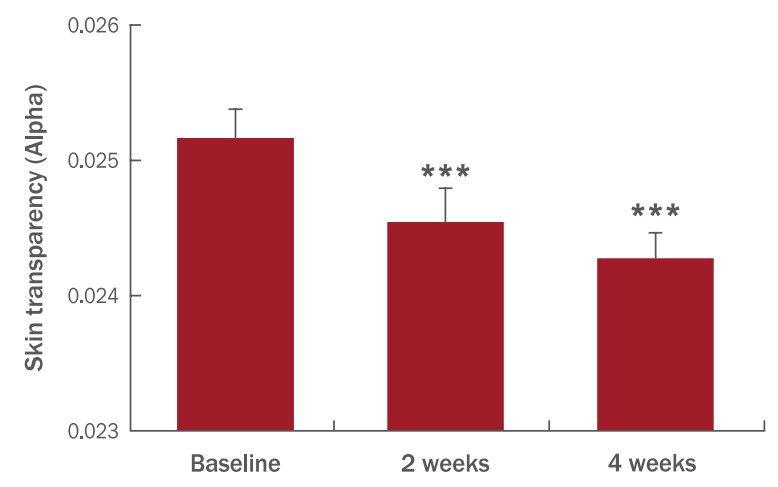

Figure 5. Effects of bee pollen on skin transparency.

Twenty volunteers participated in a clinical study, and facial skin transparency was tested with Translucency meter TLS850 after applying bee pollen 2 and 4 weeks. Skin transparency was improved at both 2 and 4 weeks after bee pollen application. Data are $\mathrm{M} \pm$ S.E. ${ }^{* * *} p<0.001$ compared to before bee pollen application.

4 주 후에 측정한 결과에서는 더욱 개선되어 $22.3 \%$ 의 개선율을 보였다 (Figure 4).

\section{4) 피부 투명도 측정 결과}

나노화 벌 화분을 주성분으로 하는 앰플을 사용한 후 얼굴 볼 부 위의 피부 투명도를 측정한 결과, 사용 2 주만에 $2.4 \%$ 의 개선율을 보였다. 사용 4 주 후에 측정한 결과에서는 더욱 개선되어 $3.9 \%$ 의 개선율을 보였다(Figure 5).

5) 피부 멜라닌 측정 결과

나노화 벌 화분을 주성분으로 하는 앰플을 사용한 후 얼굴 볼 부

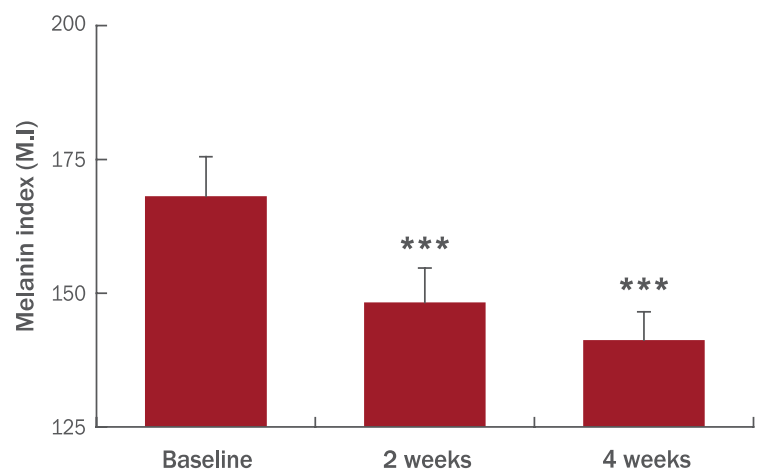

Figure 6. Effects of bee pollen on melanin index.

Twenty volunteers participated in a clinical study, and the melanin index was tested with the Mexameter ${ }^{\circledR}$ MX 18 after applying bee pollen 2 and 4 weeks. The melanin index was improved at both 2 and 4 weeks after bee pollen application. Data are $\mathrm{M} \pm \mathrm{S}$.E. ${ }^{* * *} p<0.001$ compared to before bee pollen application.

위의 멜라닌 지수를 측정한 결과, 사용 2 주만에 $11.4 \%$ 의 개선율을 보였다. 사용 4 주 후에 측정한 결과에서는 더욱 개선되어 $15.2 \%$ 의 개선율을 보였다(Figure 6).

벌 화분이 항염증 작용, 혈중 콜레스테롤 저하, 체내 해독 작용, 항산화 작용 및 양성 전립선 비대증의 완화 등 다양한 약리작용이 있는 것으로 알려져 왔으나, 피부에 미치는 효과에 관한 연구는 비 교적 최근에 시작하였다. 대표적으로는, 벌 화분의 항멜라닌 효과 와 강력한 항산화 작용에 따른 항노화 효능이 보고된 바 있다(Kim et al., 2015; Pascoal et al., 2014). 그러나 Kim et al. (2015)의 연 구에서도 알 수 있듯이 벌 화분의 유효성분 추출률과 효능은 사용 된 용매, 추출시간, 온도 등 다양한 조건에 의해 조성과 함량이 크 게 영향을 받는다. 예를 들면, tyrosinase를 억제하는 효능은 사용 한 용매 중 ethanol 추출물이 가장 우수했으며, $n$-hexane 추출물의 경우에는 ethanol 추출물의 약 $20 \%$ 에 불과하였다(Kim et al., 2015). 또한, ethanol 추출물의 경우에도 외피를 완전히 파괴하는 것이 아니 므로 벌 화분이 갖는 유효성분을 $100 \%$ 추출했다고 보기 어렵다. 이 러한 결과로 볼 때, 벌 화분을 화장품 원료로 사용할 때에는 유효성 분의 추출률이 일정치 않거나 매우 낮아 본 임상시험을 통해서 밝힌 주름개선, 미백, 보습 등의 효과를 기대하기 어려웠다. 이에 비하여 본 연구진이 제시한 습식 나노화 공정은 멸균수를 용매로 하여 외피 를 파괴하는 공정이므로 추출된 유효성분의 조성과 추출률이 매우 우수하고, 안정하므로 화장품 원료로 사용하기에 매우 적절하다.

\section{3. 나노화 벌 화분의 피부자극 측정결과}

피부자극시험에 참여한 시험대상자는 모두 33명이었으며 중도 탈 락자 없이 모두 시험을 완료하였다. 나노화 벌 화분을 포함하는 앰플, 세럼, 크림을 제조하여(Table 1) 일차자극 인체적용시험을 진행한 결 
과, 피부 자극 지수가 각각 $0.08,0.20,0.18$ 로 판정기준에 따라 모두 비자극성 $(0.00-0.25)$ 으로 판정되었다. 또한 인체적용시험에서 홍반, 부종, 인설, 가려움, 자통, 작열감 등 이상반응은 나타나지 않았다.

벌 화분은 꽃가루가 꿀 및 벌의 침과 함께 응집된 물질로서 피부 자극 또는 알러지 반응을 유발할 수 있는 것으로 알려져 있다. 예 를 들어, 벌 화분 또는 이를 포함하는 영양제에 의한 아나필락시 스(anaphylaxis) 반응이 보고된 바 있으며, 섭취 시 위장병 등을 유발하는 것으로 보고되었다(Choi et al., 2015; Güç et al., 2015; Jagdis \& Sussman, 2012; Nonotte-Varly, 2015). 반면에, 벌 화 분의 우수한 항알러지 및 항염증 효과에 관한 연구도 최근에 활발 히 발표되고 있지만 벌 화분의 알러지 또는 피부자극에 미치는 효 과는 아직 분명하지 않다(Denisow \& Denisow-Pietrzyk, 2016; Ishikawa et al., 2008; Medeiros et al., 2008; Moita et al., 2013). 그러나, 최근의 연구결과에 따르면 꽃가루에 의한 알러지는 충매화 보다는 주로 풍매화에 의해 일어나는 것이 알려져, 풍매화의 화분 이 벌 화분에 혼합될 때 알러지 또는 피부자극을 발생할 수 있는 것 으로 추측되고 있다(Jagdis \& Sussman, 2012). 이러한 결과와 일 치하여 본 연구에 사용된 벌 화분은 충매화분이므로 피부에 자극적 이지 않아 화장품 원료로 안전하게 사용될 수 있음을 알 수 있다.

\section{Conclusion}

본 연구를 통해 습식 나노 공정에 따른 벌 화분의 항산화 및 세포 보호효과의 증강과 이를 이용한 화장품의 임상적 효능을 조사하였 다. 이전의 연구에서 본 연구진은 화분의 외피를 제거하기 위한 습 식 나노 공정을 확립하였다(Choi et al., 2016). 이러한 공정을 통해 화분의 외피를 효과적으로 파쇄하였고 화분 활성성분의 유출을 약 10 배 증가시켰다. 이러한 결과를 바탕으로 본 연구에서는 습식 나 노 공정을 통해 화분의 우수한 항산화 효과와 세포보호효과를 증명 하였다. 또한, 나노화 벌 화분의 화장품으로의 기능성을 알아보기 위하여 나노화 벌 화분을 주성분으로 하는 시험물질을 이용하여 임 상시험을 진행하였다. 그 결과, 4 주 간에 걸쳐 진행된 연구에서 피 부 결, 피부 수분, 눈가 주름, 피부 투명도 및 멜라닌 지수에서 유의 한 개선 효과를 발견하였다. 특히 4 주간의 피부자극시험에서도 거 의 피부에 유해성이 나타나지 않음을 관찰하였다.

이상의 결과로 볼 때, 나노화 벌 화분은 항산화 효과를 바탕으로 하여 항피부노화 효과가 기대되며 임상시험 결과를 볼 때 우수한 화장품 원료로 사용될 수 있음을 보여준다. 그러나, 주목할 점은 벌 화분은 채취 시기와 장소에 따라 꽃의 종류가 다르므로 유효성분의 함량과 조성에 차이를 보이게 된다. 따라서 벌 화분을 산업적으로 이용하기 위해서는 채취 시기와 장소를 일정하게 유지할 필요가 있 으며 활성을 나타내는 내부 지표물질의 설정과 관리가 필요하다. 또 한 본 연구에서 제시한 습식 나노 분쇄 기술은 모든 천연소재에 적
용 가능한 안전한 기술로서 유효성분의 추출에 어려움이 있는 천연 물의 추출률을 획기적으로 개선하여 화장품 등 외용으로 적용할 때 피부를 통한 흡수율을 현저히 개선시킬 수 있을 것으로 기대된다.

\section{Acknowledgements}

본 논문은 중소기업청에서 지원하는 2015년도 산학연협력 기술개 발사업(No.C0332582)의 연구수행으로 인한 결과물임을 밝힙니다.

\section{References}

Baltrušaitytė V, Venskutonis PR, Čeksterytė V. Radical scavenging activity of different floral origin honey and beebread phenolic extracts. Food Chemistry, 101: 502514, 2007.

Choi JH, Jang YS, Oh JW, Kim CH, Hyun IG. Bee pollen-induced anaphylaxis: a case report and literature review. Allergy, Asthma \& Immunology Research, 7: 513-517, 2015.

Choi YS, Suh HJ, Chung IK. Enhanced extraction of bioactive compounds from bee pollen by wet-grinding technology. Journal of Life Science, 26: 651-656, 2016.

Denisow B, Denisow-Pietrzyk M. Biological and therapeutic properties of bee pollen: a review. Journal of the Science of Food and Agriculture, 96: 4303-4309, 2016.

Fanali C, Dugo L, Rocco A. Nano-liquid chromatography in nutraceutical analysis: determination of polyphenols in bee pollen. Journal of Chromatography A, 1313: 270-274, 2013.

Güç BU, Asilsoy S, Canan O, Kayaselçuk F. Does bee pollen cause to eosinophilic gastroenteropathy? Turkish Archives of Pediatrics, 50: 189-192, 2015.

Ishikawa Y, Tokura T, Nakano N, Hara M, Niyonsaba F, Ushio H, Yamamoto Y, Tadokoro T, Okumura K, Ogawa H. Inhibitory effect of honeybee-collected pollen on mast cell degranulation in vivo and in vitro. Journal of Medicinal Food, 11: 14-20, 2008.

Jagdis A, Sussman G. Anaphylaxis from bee pollen supplement. Canadian Medical Association Journal, 184: 1167-1169, 2012.

Kim JE, Lee DE, Lee KW, Son JE, Seo SK, Li J, Jung SK, Heo YS, Mottamal M, Bode AM, et al. Isorhamnetin suppresses skin cancer through direct inhibition of MEK1 and PI3-K. Cancer Prevention Research, 4: 582591, 2011. 
Kim SB, Jo YH, Liu Q, Ahn JH, Hong IP, Han SM, Hwang BY, Lee MK. Optimization of extraction condition of bee pollen using response surface methodology: correlation between anti-melanogenesis, antioxidant activity, and phenolic content. Molecules, 20: 19764-19774, 2015.

Komosinska-Vassev K, Olczyk P, Kaźmierczak J, Mencner L, Olczyk K. Bee pollen: chemical composition and therapeutic application. Evidence-Based Complementary and Alternative Medicine, 2015: 297425, 2015.

Lee S, Han HS, An IS, Ahn KJ. Effects of amentoflavone on anti-inflammation and cytoprotection. Asian Journal of Beauty and Cosmetology, 14: 201-211, 2016.

Medeiros KC, Figueiredo CA, Figueredo TB, Freire KR, Santos FA, Alcantara-Neves NM, Silva TM, Piuvezam MR. Anti-allergic effect of bee pollen phenolic extract and myricetin in ovalbumin-sensitized mice. Journal of Ethnopharmacology, 119: 41-46, 2008.

Moita E, Gil-Izquierdo A, Sousa C, Ferreres F, Silva LR, Valentão P, Domínguez-Perles R, Baenas N, Andrade PB. Integrated analysis of COX-2 and iNOS derived inflammatory mediators in LPS-stimulated RAW macrophages preexposed to Echium plantagineum L. bee pollen extract. PLoS One, 8: e59131, 2013.

Morais M, Moreira L, Feás X, Estevinho LM. Honeybeecollected pollen from five Portuguese natural parks: palynological origin, phenolic content, antioxidant properties and antimicrobial activity. Food and Chemical Toxicology, 49: 1096-1101, 2011.

Nogueira C, Iglesias A, Feás X, Estevinho LM. Commercial bee pollen with different geographical origins: a comprehensive approach. International Journal of Molecular Sciences, 13: 11173-11187, 2012.
Nonotte-Varly C. Allergenicity of Artemisia contained in bee pollen is proportional to its mass. European Annals of Allergy and Clinical Immunology, 47: 218-224, 2015.

Orzáez Villanueva MT, Díaz Marquina A, Bravo Serrano R, Blazquez Abellán G. The importance of bee-collected pollen in the diet: a study of its composition. International Journal of Food Sciences and Nutrition, 53: 217-224, 2002.

Pascoal A, Rodrigues S, Teixeira A, Feás X, Estevinho LM. Biological activities of commercial bee pollens: antimicrobial, antimutagenic, antioxidant and antiinflammatory. Food and Chemical Toxicology, 63: 233239, 2014.

Sharma DR, Wani WY, Sunkaria A, Kandimalla RJ, Sharma RK, Verma D, Bal A, Gill KD. Quercetin attenuates neuronal death against aluminum-induced neurodegeneration in the rat hippocampus. Neuroscience, 324: 163-176, 2016.

Yang JH, Shin BY, Han JY, Kim MG, Wi JE, Kim YW, Cho IJ, Kim SC, Shin SM, Ki SH. Isorhamnetin protects against oxidative stress by activating Nrf2 and inducing the expression of its target genes. Toxicology and Applied Pharmacology, 274: 293-301, 2014.

Zhu X, Zeng X, Zhang X, Cao W, Wang Y, Chen H, Wang T, Tsai $\mathrm{HI}$, Zhang R, Chang D, et al. The effects of quercetinloaded PLGA-TPGS nanoparticles on ultraviolet B-induced skin damages in vivo. Nanomedicine, 12: 623-632, 2016. 


\section{국문초록}

\section{새로운 화장품 원료 나노화 벌 화분의 효능}

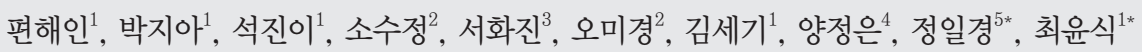

${ }^{1}$ 대구가톨릭대학교 제약산업공학과, 경상북도 경산시, 한국

${ }^{2}$ (주)엔에스비, 경상북도 영천시, 한국

${ }^{3}$ 경북테크노파크 천연소재융합연구소, 경상북도 영천시, 한국

${ }^{4}$ 대구가톨릭대학교 패션디자인과, 경상북도 경산시, 한국

${ }^{5}$ 대구가톨릭대학교 생명공학과, 경상북도 경산시, 한국

목적: 벌 화분은 일벌이 모은 꽃의 화분이 주성분이며 가장 완벽한 건강식으로 인식되어지고 있다. 벌 화분은 단백질(약 $40 \%)$, 아 미노산 그리고 플라보노이드가 매우 풍부하다. 그러나 벌 화분은 exine이라는 외피로 둘러싸여 있고 이로 인해 소화효소, 산 그리고 알칼리에 매우 안정하여 식이나 의학적 목적으로 사용하는 데 어려움이 있다. 본 연구에서는 습식 나노 분쇄 기술을 이용하여 외피 를 파괴하여 나노화 벌 화분을 제조하였고, 나노화 벌 화분의 항산화 효과와 세포보호효과, 그리고 화장품 제형의 임상적 효과에 대 해 연구하였다. 방법: 습식 나노 분쇄 공정을 통해 벌 화분을 나노화하였고 라디칼 소거 활성과 세포보호효과를 평가하였다. 또한 나노화 벌 화분을 원료로 하는 제형을 제조하여 임상시험을 수행하였다. 결과: 나노화 벌 화분은 우수한 항산화 효과를 나타내었고 $1 \%$ 나노화 벌 화분 용액은 피부세포에서 lactate dehydrogenase $(\mathrm{LDH})$ 의 분비를 $18.73 \%$ 감소시켰다. 임상시험에서도 나노화 벌 화분은 피부 결, 피부 수분 함유량, 피부 투명도 그리고 멜라닌 지수를 개선하였고 눈가의 주름을 감소시켰다. 피부자극시험에서도 나노 화분은 부작용을 유발하지 않았다. 결론: 이러한 결과로 볼 때 나노화 벌 화분은 화장품 원료로서의 우수한 가치가 있으며 피 부에 다양한 효능을 제공할 수 있다고 사료된다.

핵심어: 벌 화분, 항산화, 화장품, 보호작용, 습식분쇄기술

본 논문은 중소기업청에서 지원하는 2015년도 산학연협력 기술개발사업(No.C0332582)의 연구수행으로 인한 결과물임을 밝힙니다.

\section{참고문헌}

이송정, 한효선, 안인숙, 안규중. Amentoflavone의 항염증 및 세포 보호 효과. 아시안뷰티화장품학술지, 14: 201-211, 2016.

최윤식, 서화진, 정일경. 벌 화분에서 습식 나노화 공정에 의한 유효성분의 추출. 생명과학회지, 26: 651-656, 2016. 


\section{中文摘要}

\section{新型化妆品原料纳米蜂花粉的功效研究}

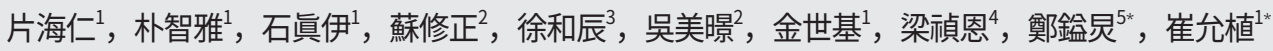

${ }^{1}$ 大邱Catholic大學製藥産業工學科，慶少北道慶山市，韩国

${ }^{2}$ (株)NSB硎究所, 慶少北道永川市, 韩国

3慶北Techno Park天然染色材料研究所，慶少北道永川市，韩国

${ }^{4}$ 大邱Catholic大學衣裳學科, 慶尙北道慶山市, 韩国

${ }^{5}$ 大邱Catholic大學生命工學科，慶尙北道慶山市，韩国

目的：蜂花粉主要由工蜂收集的花粉组成，是众所周知的一种完整的营养食品。蜂花粉富含蛋白质（约40\%)、游离氨基 酸和黄酮类化合物。然而, 蜂花粉覆盖在一个称为外壁的外墙，这个对消化酶、酸和碱具有抵抗性。因此，蜂花粉用于 营养和医疗目的是有限的。在本研究中, 我们用湿法粉碎技术去除了外壁层, 制造了纳米蜂花粉, 并且评价其抗氧 化活性、对皮肤成纤维细胞的保护作用以及作为化妆品剂型的潜在的临床效果。方法: 采用湿法粉碎技术制备了纳 米蜂花粉, 并评价其自由基清除活性和细胞保护作用。还有以纳米蜂花粉为原料制备了化妆品剂型, 并进行临床实 验。结果：蜂花粉具有良好的抗氧化活性，含有1\%蜂花粉溶液能降低 $18.73 \%$ 皮肤成纤维细胞乳酸脱氢酶的分泌。此外， 临床研究表明, 蜂花粉改善皮肤粗糙度、皮肤水分含量、透明度以及黑色素指数，并减少了眼睛周围的皱纹。并且蜂花 粉对皮肤没有产生任何不良影响。结论：从以上的结果表明，蜂花粉作为化妆品原料具有优秀的价值，为皮肤提供各种 有益效果。

关键词: 蜂花粉，抗氧化，化妆品，保护作用，湿法粉碎技术 